\title{
THE NOVEMBER MEETING IN DURHAM
}

The five hundred and fifty-first meeting of the American Mathematical Society was held at Duke University in Durham, North Carolina, on Friday and Saturday, November 29, 30, 1958. About 125 persons registered, including 102 members of the Society.

By Invitation of the Committee to Select Hour Speakers for Southeastern Sectional Meetings, Professor E. E. Floyd of the University of Virginia addressed the Society on Friday on the topic, Compact groups of transformations. Professor M. K. Fort, Jr. presided at this session.

There were four sessions for contributed papers and one session for late papers, with Professors J. H. Roberts, Tomlinson Fort, J. J. Gergen, Alfred Brauer, and J. H. Wahab presiding. Papers numbered 551-3, 551-14, and 551-20 were presented by title. Papers with numbers 551-9, 551-18, and 551-19 were presented, respectively by M. L. Curtis, W. G. Horstman, and R. V. Wisner. Abstracts of the papers presented in the session for late papers will appear in the December 1958 and February 1959 issues of the NOTICES of the American Mathematical Society.

G. B. HuFf, Associate Secretary 